\title{
Urgences
}

\section{Esquisse d'une fuite}

\section{Danielle Hawey}

Numéro 13, mars 1986

\section{Éclats d'atelier}

URI : https://id.erudit.org/iderudit/025197ar

DOI : https://doi.org/10.7202/025197ar

Aller au sommaire du numéro

\section{Éditeur(s)}

Urgences

\section{ISSN}

0226-9554 (imprimé)

1927-3924 (numérique)

Découvrir la revue

Citer ce document

Hawey, D. (1986). Esquisse d'une fuite. Urgences, (13), 12-12.

https://doi.org/10.7202/025197ar

Ce document est protégé par la loi sur le droit d'auteur. L'utilisation des services d'Érudit (y compris la reproduction) est assujettie à sa politique d'utilisation que vous pouvez consulter en ligne.

https://apropos.erudit.org/fr/usagers/politique-dutilisation/
Cet article est diffusé et préservé par Érudit.

Érudit est un consortium interuniversitaire sans but lucratif composé de l'Université de Montréal, l'Université Laval et l'Université du Québec à Montréal. Il a pour mission la promotion et la valorisation de la recherche. https://www.erudit.org/fr/ 


\section{ESQUISSE D'UNE FUITE Danielle Hawey}

L'heure indolente finit de dégorger les rumeurs diffuses de ses veines mutilées. Ne restent que les fumées grises et onduleuses qui s'élèvent le long des trottoirs fissurés. Ellipse d'une nuit sulfurée, le tumulte s'estompe. Lentement. Toujours tronqués les sous-entendus. New \& fresh. Qu'ils disent, tu vois. Systole sous verrou. Songes rompus. Espoir suspendu.

Un souffle mystérieux tout près, une effluve dérivée d'une profondeur innommée. Premiers vertiges. Glissement fluide et lumineux de gestes en kyrielle. Têtes en désordre sur des rives intemporelles. Mouvements, ondoiements, poursuite osmotique.

Sirius pointe sur un profil d'horizon, retient un moment, puis délivre entre ses doigts mes dernières flexions de voix. Les sirènes se sont tues, un peu essoufflées. Dénouent leurs filets, m'éveillent de quelques relents de sel. Je pense les entendre murmurer que l'énigme reste toujours irrésolue. 